\title{
Editorial: Brand management - Is there any more to be said?
}

When this journal was founded, ten years ago, I wondered whether the development of brand management was a time-limited phenomenon. It is a well-established fact that there are fashion cycles in marketing. Moreover, they are not limited to the rag trade. Now in its tenth year, this journal is evidence that fertile minds are still exploring new ideas and new concepts as they apply to managing the brand.

It is as easy as ABC, or is it? Kamal Ghose (Otago Polytechnic, Christchurch, New Zealand), in the first paper in this issue, explores the problem of creating the desired customer experience when using the Internet as a communications channel. The organisation that can learn quickly about its Internet customers and how they respond will survive in the digital media jungle. That in turn requires that all the Internet brand proprietors must be wired into the 'total customer experience' of their brand. The way to do it? Follow Ghose's ABC, an abbreviation for 'anchoring the brand concept' (not to be confused with other ABC, the Audit Bureau of Circulation). $\mathrm{ABC}$ is a system for ongoing brand anchor audits, a set of action learning principles. Given the demise of thousands of dot-com companies, one needs to be convinced that success is rooted in ABC. I urge the reader to come to the paper with an open mind.

An appreciation of the need to advertise during a recession is one of the acid tests of vigorous marketing management. Advertising is an invest- ment, not a cost, hence investing to ensure survival and eventual reward during the subsequent upturn is a theory too rarely applied by those who advocate proactive market management. Thomas Kamber (Columbia University, New York, USA) is not a witch doctor. The author of the second paper in this issue is a believer in good old-fashioned regression analysis, and he has studied, in depth, adspend behaviour during the 1990-1 US recession. This is an excellent study technically, and provides grist for the mill for those who believe and preach that there is a positive relationship between advertising expenditure and business performance. While recognising some of the limitations inherent in his methodology, Kamber nevertheless makes a convincing case for the argument that recession provides the proactive marketer with opportunities to maximise returns on advertising investment. Brand managers must take these findings seriously, for they tell them that when life looks both difficult and uncertain, advertising expenditure may produce the greatest rewards.

The link between branding and consumer goods is taken as proven for most us who live in a world dominated by brands. But what about business-tobusiness (B2B) companies? Can diversified or industrial $\mathrm{B} 2 \mathrm{~B}$ companies learn anything from the burgeoning brand management literature? Elliot Schreiber (McMaster University, Ontario, Canada) builds his paper on two abbreviations, FUD and CBD. At the point-of-purchase decision, fear, uncer- 
tainty and doubt (FUD) persist in the minds of industrial purchasing agents. What can be done about FUD? In the $\mathrm{B} 2 \mathrm{~B}$ context, the purchasing decision is usually more complex than in the case of ultimate consumer buyer behaviour. Hence CBD, the complexity of the buying decision. Schreiber claims to offer in this paper a brand strategy framework for B2B. He shows us how to research FUD and CBD, and how that research can yield both brand and communications strategies. As a bonus, you may learn about Brand Get-Give Analysis, which will help partnerships gain insight into the value of partnerships. You get all this for the price of a year's subscription to the Journal of Brand Management. Banish FUD and banish CBD at a stroke.

The editors of this journal have boundless horizons. We have recently published a number of papers designated as 'national brand building'. This issue contains two further contributions to this topic.

Education, particularly tertiary education, has become a global product, and institutions of higher education all over the world (as it appears to one who looks out on the world from a Scottish university) are competing for students no matter where they happen to be graduating from. Srikatanyoo and Gnoth (University of Otago, Dunedin, New Zealand) have taken the first steps in trying to model the world market as seen from universities in a particular country. How does country image assist in the marketing of higher education to the global market? Quite properly, they advocate good market research among students, ie the customers.

Finally, Beverland (Monash Univer- sity, Caulfield East, Australia) and Lindgreen (Technical University, Eindhoven, Holland) return to a topic that I, as the co-author of an internationally acclaimed and used international marketing textbook, ${ }^{1}$ thought had become either passé or politically incorrect. Does country of origin (COO) matter any more? Does COO influence buyer's perceptions and decisions? Surely NIKE represents the real world, a company that happens to have a management team in Seattle, but owns no factories. Do your kids know where their sneakers, running shoes or football boots were made? What has COO to do with all this? Using six New Zealand agribusinesses as their sample, all of whom use COO in their global marketing programmes, Beverland and Lindgreen explore this complex topic in a very thorough manner. When does COO help and enhance, when does it not work, or matter? The authors are humble enough to acknowledge the complexity of the issue (I guarantee a citation in the next issue of our book - I admire humility in research), and academic researchers will thank them for demonstrating that this particular hobbyhorse has a lot of life left in it. Further research is required, thank goodness.

There are some very rich pickings in this issue. And, no doubt, there is much more to be said...

\section{Michael Thomas Editorial Board}

\section{References}

(1) Paliwoda, S. and Thomas, M.J. (1997) 'International Marketing', 3rd Edn., Butterworth Heinemann, Oxford. 